\title{
YURISDIKSI PERADILAN TERHADAP PRAJURIT TENTARA NASIONAL INDONESIA SEBAGAI PELAKU TINDAK PIDANA
}

\author{
Niken Subekti Budi Utami; Supriyadi \\ Fakultas Hukum universitas Gadjah Mada \\ Email : niken.subekti@mail.ugm.ac.id; supriyadi@ugm.ac.id
}

\begin{abstract}
This research intends to find the answers of two problems. First, the factors that led to the unimplemented jurisdiction of the General Court of the Indonesian Armed Forces (TNI) that perform general crime as mandated by Decree No. VII / MPR / 2000 and Act No. 34 of 2004. Second, the perception of the military conception of justice with jurisdiction over soldiers who committed the crime. This study is a normativeempirical law that uses secondary data and primary data. The data collected by the study of documents and interviews. The data analysis using qualitative methods. The results showed that first the jurisdiction of the General Court of the soldiers who committed the crime can not be implemented because of the general Act No. 31 of 1997 on Military Justice has not been revised by Law Military Justice as new, second that some of the military still wants the soldiers who committed the crime, criminal acts both military and general crime, is in the jurisdiction of Military Justice.
\end{abstract}

Keywords: Jurisdiction Court, Indonesian Army Forces (TNI)I, Crime.

\begin{abstract}
Abstrak
Penelitian ini bertujuan untuk menemukan jawaban atas dua permasalahan. Pertama, faktor-faktor yang menyebabkan belum diimplementasikannya yurisdiksi Peradilan Umum terhadap prajurit Tentara Nasional Indonesia (TNI) yang melakukan tindak pidana umum sebagaimana diamanatkan oleh Ketetapan MPR Nomor VII/MPR/2000 dan Undang-Undang Nomor 34 Tahun 2004. Kedua, persepsi kalangan militer mengenai konsepsi peradilan yang berwenang mengadili prajurit TNI yang melakukan tindak pidana. Penelitian ini merupakan penelitian hukum normatif-empiris yang menggunakan data sekunder dan data primer. Pengumpulan data dilakukan dengan studi dokumen dan wawancara. Analisis data dilakukan dengan menggunakan metode kualitatif. Hasil penelitian menunjukkan bahwa, pertama yurisdiksi Peradilan Umum terhadap prajurit TNI yang melakukan tindak pidana umum belum dapat diimplementasikan karena Undang-Undang Nomor 31 Tahun 1997 tentang Peradilan Militer belum direvisi dengan Undang-Undang Peradilan Militer yang baru, kedua bahwa beberapa kalangan militer tetap menghendaki agar prajurit TNI yang melakukan tindak pidana, baik tindak pidana militer maupun tindak pidana umum, berada pada yurisdiksi Peradilan Militer.
\end{abstract}

Kata Kunci: Yurisdiksi Peradilan, Prajurit TNI, Tindak Pidana.

\section{A. Pendahuluan}

Pertahanan negara sebagai salah satu fungsi pemerintahan negara Indonesia merupakan faktor yang sangat hakiki dalam kehidupan bernegara, yaitu menjamin kelangsungan hidup negara Indonesia. Alat negara yang mempunyai peran dan tugas penting dalam rangka penyelenggaraan sistem pertahanan negara adalah militer, dalam hal ini Tentara Nasional Indonesia.

Dalam rangka mendukung dan menjamin terlaksananya peran tugas TNI tersebut, maka telah diadakan dan diberlakukan peraturanperaturan khusus yang hanya berlaku bagi prajurit TNI, di samping peraturan-peraturan yang bersifat umum. Peraturan-peraturan yang bersifat khusus dan hanya berlaku bagi prajurit TNI inilah yang dikenal dengan hukum militer.

Salah satu peraturan yang bersifat khusus dan hanya berlaku bagi prajurit TNI adalah UndangUndang Nomor 31 Tahun 1997 tentang Peradilan Militer yang di dalamnya mengatur ketentuan mengenai peradilan yang berwenang mengadili (yurisdiksi peradilan) terhadap prajurit TNI yang melakukan tindak pidana. Ketentuan mengenai yurisdiksi peradilan terhadap prajurit TNI yang melakukan tindak pidana tersebut terdapat dalam Pasal 9 angka 1 Undang-Undang Nomor 31 Tahun 1997 yang pada dasarnya menegaskan bahwa

Yurisdiksi Peradilan terhadap Prajurit Tentara ... 
peradilan yang berwenang mengadili prajurit TNI yang melakukan tindak pidana adalah Peradilan Militer.

Tindak pidana yang dimaksud dalam Pasal 9 angka 1 Undang-Undang Nomor 31 Tahun 1997 di atas mencakup tindak pidana militer maupun tindak pidana umum. Namun demikian, ketentuan mengenai yurisdiksi peradilan terhadap prajurit TNI yang melakukan tindak pidana mengalami perubahan yang cukup signifikan setelah bergulirnya reformasi. Hal tersebut dapat dilihat dalam ketentuan Pasal 3 ayat (4) huruf a Ketetapan MPR Nomor VII/MPR/2000 dan dipertegas kembali dalam Pasal 65 ayat (2) Undang-Undang Nomor 34 Tahun 2004 tentang Tentara Nasional Indonesia. Kedua pasal tersebut pada intinya menyatakan bahwa prajurit TNI tunduk kepada kekuasaan Peradilan Militer dalam hal melakukan tindak pidana militer dan tunduk kepada kekuasaan Peradilan Umum dalam hal melakukan tindak pidana umum.

Bertolak dari ketentuan Pasal 3 ayat (4) huruf a Ketetapan MPR Nomor VII/MPR/2000 dan Pasal 65 ayat (2) Undang-Undang Nomor 34 Tahun 2004 di atas dapat diketahui adanya dua yurisdiksi peradilan yang berlaku bagi prajurit TNI yang melakukan tindak pidana, yaitu Peradilan Militer dan Peradilan Umum. Peradilan Militer berwenang mengadili prajurit TNI yang melakukan tindak pidana militer, sedangkan Peradilan Umum berwenang mengadili prajurit TNI yang melakukan tindak pidana umum. Hal ini berbeda dengan yurisdiksi peradilan yang berlaku bagi prajurit TNI yang melakukan tindak pidana dalam UndangUndang Nomor 31 Tahun 1997 yang hanya diberikan kepada Peradilan Militer.

Ironisnya, realitas menunjukkan bahwa ketentuan Pasal 3 ayat (4) huruf a Ketetapan MPR Nomor VII/MPR/2000 dan Pasal 65 ayat (2) Undang-Undang Nomor 34 Tahun 2004 belum juga diimplementasikan hingga saat ini, terutama menyangkut yurisdiksi Peradilan Umum terhadap prajurit TNI yang melakukan tindak pidana umum. Akibatnya, implementasi yurisdiksi peradilan bagi prajurit TNI yang melakukan tindak pidana umum masih tetap menggunakan dan mendasarkan pada Undang-Undang Nomor 31 Tahun 1997. Hal ini sebagai konsekuensi dari ketentuan Pasal 65 ayat (3) Undang-Undang Nomor 34 Tahun 2004 yang pada intinya menyatakan bahwa apabila yurisdiksi Peradilan Umum tidak berfungsi, maka prajurit TNI yang melakukan tindak pidana diadili di Peradilan Militer, baik tindak pidana militer maupun tindak pidana umum.

Situasi dan kondisi di atas memperlihatkan adanya pertentangan (gap) antara ketentuan normatif (das Sollen) dengan realitas di lapangan (das Sein) menyangkut yurisdiksi Peradilan Umum terhadap prajurit TNI yang melakukan tindak pidana umum.

Berdasarkan latar belakang pemikiran di atas, menarik unruk dilakukan penelitian mengena : Faktor-faktor yang menyebabkan belum diimplementasikannya yurisdiksi Peradilan Umum terhadap prajurit TNI yang melakukan tindak pidana umum sebagaimana diamanatkan dalam Ketetapan MPR Nomor VII/MPR/2000 dan Undang-Undang Nomor 34 Tahun 2004 serta persepsi kalangan militer mengenai konsepsi peradilan yang berwenang mengadili prajurit TNI yang melakukan tindak pidana.

\section{B. Metode Penelitian}

Penelitian ini merupakan penelitian normatif empiris. Data yang diperlukan dalam penelitian ini adalah data sekunder yang dilakukan dengan cara penelitian pustaka dan data primer yang diperoleh dari penelitian lapangan, dengan melakukan wawancara pada narasumber yaitu hakim militer pada Pengadilan Militer II-11 Yogyakarta dan oditur militer pada oditurat Militer II-11 Yogyakarta. Data yang diperoleh kemudian dianalisis dengan metode deskriptif kualitatif.

\section{Hasil Penelitian dan Pembahasan}

1. Faktor Penyebab Belum Diimplementasikannya Yurisdiksi Peradilan Terhadap Prajurit Tentara Nasional Indonesia Sebagai Pelaku Tindak Pidana

Yurisdiksi peradilan atau kewenangan pengadilan untuk memeriksa dan memutus suatu perkara dapat dibedakan menjadi yurisdiksi peradilan yang bersifat absolut dan yurisdiksi peradilan yang bersifat relatif. Yurisdiksi peradilan yang bersifat absolut atau sering dikenal dengan kompetensi absolut berkaitan dengan kewenangan lingkungan peradilan untuk memeriksa dan memutus suatu perkara, sedangkan yurisdiksi peradilan yang bersifat relatif atau sering disebut dengan kompetensi relatif berhubungan dengan kewenangan pengadilan sejenis yang dalam memeriksa dan memutus suatu perkara (Darwan Prinst, 2003: 6 dan 9).

Pengaturan yurisdiksi peradilan di Indonesia sebenarnya dapat dilihat dari ketentuan Pasal 24 Undang-Undang Dasar Negara Republik Indonesia Tahun 1945, kemudian ditindak lanjuti dengan keluarnya 
UU No 14 tahun 1970 dan kemudian pada saat ini telah diganti dengan UU No 48 tahun 2009.

Dalam Pasal 18 Undang-Undang Nomor 48 Tahun 2009 mengatur dan menegaskan bahwa kekuasaan kehakiman dilakukan oleh sebuah Mahkamah Agung dan badan peradilan yang berada di bawahnya dalam lingkungan Peradilan Umum, lingkungan Peradilan Agama, lingkungan Peradilan Militer, lingkungan Peradilan Tata Usaha Negara dan oleh sebuah Mahkamah Konstitusi.

Peraturan perundang-undangan yang kemudian menjadi landasan hukum bagi Peradilan Militer di Indonesia hingga saat ini adalah Undang-Undang Nomor 31 Tahun 1997 tentang Peradilan Militer yang diundangkan pada tanggal 15 oktober 1997. Dalam Pasal 9 Undang-Undang Nomor 31 Tahun 1997 dinyatakan bahwa Peradilan Militer berwenang mengadili tindak pidana yang dilakukan oleh seseorang yang pada waktu melakukan tindak pidana adalah :

a. Prajurit, menurut Pasal 1 angka 42 UU No 31 Tahun 1997 adalah prajurit ABRI yang terdiri dari TNI dan PoLRI ;

b. Seseorang yang berdasarkan undangundang dipersamakan dengan prajurit;

c. Anggota suatu golongan atau jawatan atau badan yang dipersamakan atau dianggap sebagai prajurit berdasarkan undang-undang;

d. Seseorang yang tidak termasuk dalam huruf a, b atau c di atas, tetapi atas keputusan Panglima dengan persetujuan Menteri Kehakiman harus diadili oleh suatu pengadilan dalam lingkungan Peradilan Militer.. Dalam konteks pemisahan TNI dan PoLRI, yang dimaksud Panglima adalah Panglima TNI dan yang dimaksud Mneteri Kehakiman adalah Menteri Hukum dan HAM.

Berdasarkan ketentuan Pasal 9 UndangUndang Nomor 31 Tahun 1997 di atas dapat disimpulkan bahwa kewenangan mengadili tindak pidana yang dilakukan oleh prajurit TNI berada pada Peradilan Militer, baik tindak pidana umum maupun tindak pidana militer. Tindak pidana militer merupakan tindak pidana yang hanya diatur dan dirumuskan dalam KUHPM. Sedangkan tindak pidana umum merupakan tindak pidana yang pengaturan dan perumusannya terdapat dalam KUHP maupun peraturan perundangundangan pidana lainnya di luar KUHP.
Dalam perkembangannya terjadi perubahan paradigma mengenai yurisdiksi peradilan terhadap prajurit TNI yang melakukan tindak pidana setelah reformasi. Sebagaimana diketahui bahwa gerakan reformasi di Indonesia telah mendorong adanya tuntutan perubahan di berbagai aspek kehidupan berbangsa dan bernegara. Salah satu tuntutan perubahan yang mendasar adalah perlunya dilakukan penataan kembali atau reposisi terhadap eksistensi militer Indonesia, yaitu Tentara Nasional Indonesia (TNI) dan Kepolisian Negara Republik Indonesia (PoLRI), yang terintegrasi dalam Angkatan Bersenjata Republik Indonesia (ABRI).

Hal tersebut disebabkan karena integrasi TNI dan PoLRI ke dalam ABRI dipandang sebagai manifestasi pengingkaran kecenderungan yang berlaku secara universal mengenai pengelolaan pertahanan dan keamanan negara ( Muhammad Fajrul Falaakh, dkk, 2001: 140-141). Kedua institusi ini memiliki doktrin yang berbeda secara fundamental dalam rangka menjalankan peran dan tugasnya. TNI memiliki doktrin yang berorientasi pada penghancuran musuh untuk mempertahankan kedaulatan negara, sedangkan PoLRI menjalankan tugas pemerintahan di bidang penegakan hukum dengan kewenangan untuk melakukan penyelidikan dan penyidikan terhadap adanya dugaan suatu tindak pidana.

Reposisi TNI dan PoLRI dalam perkembangannya telah mendapatkan landasan hukum yang kuat melalui Sidang Tahunan Majelis Permusyawaratan Rakyat (MPR) yang dilaksanakan pada tanggal 7 sampai dengan 18 Agustus 2000. Landasan hukum reposisi TNI dan PoLRI tersebut dapat dilihat dari dua Ketetapan MPR yang dihasilkan dalam Sidang Tahunan MPR, yaitu Ketetapan MPR Nomor VI/MPR/2000 tentang Pemisahan Tentara Nasional Indonesia dan Kepolisian Negara Republik Indonesia dan Ketetapan MPR Nomor VII/MPR/2000 tentang Peran Tentara Nasional Indonesia dan Peran Kepolisian Negara Republik Indonesia. Kedua Ketetapan MPR ini pada hakikatnya merumuskan ulang kedudukan dan peran TNI dan PoLRI di Indonesia.

Dalam Pasal 1 Ketetapan MPR Nomor VI/MPR/2000 ditegaskan bahwa TNI dan PoLRI terpisah secara kelembagaan sesuai dengan peran dan fungsinya masing-masing. Menurut Konsideran Ketetapan MPR Nomor 
VI/MPR/2000 pemisahan kelembagaan TNI dan PoLRI ini didasarkan pada pertimbangan bahwa kebijakan di bidang pertahanan dan keamanan yang mengintegrasikan TNI dan PoLRI ke dalam ABRI telah menimbulkan kerancuan dan tumpang tindih antara peran dan fungsi TNI sebagai kekuatan pertahanan negara dengan peran dan tugas PoLRI sebagai kekuatan keamanan dan ketertiban masyarakat.

Dalam Pasal 2 ayat (1) dan ayat (2) Ketetapan MPR Nomor VII/MPR/2000 menyatakan lebih lanjut bahwa TNI merupakan alat negara yang berperan dalam rangka pertahanan negara dan memiliki tugas pokok menegakkan kedaulatan negara, keutuhan wilayah Negara Kesatuan Republik Indonesia (NKRI) yang berdasarkan Pancasila dan Undang-Undang Dasar Negara Republik Indonesia Tahun 1945, serta melindungi segenap bangsa dan seluruh tumpah darah Indonesia dari ancaman dan gangguan terhadap keutuhan bangsa dan negara. Sedangkan menurut Pasal 6 ayat (1) Ketetapam MPR Nomor VII/MPR/2000, PoLRI merupakan alat negara yang memiliki peran dalam memelihara keamanan dan ketertiban masyarakat, menegakkan hukum, memberikan pengayoman dan pelayanan kepada masyarakat.

Menurut Pasal 3 ayat (1) Ketetapan MPR Nomor VI/MPR/2000, pemisahan kelembagaan TNI dan PoLRI dari ABRI menyebabkan eksistensi militer Indonesia hanya meliputi Tentara Nasional Indonesia (TNI) yang terdiri dari Angkatan Darat, Angkatan Laut dan Angkatan Udara. Hal ini berbeda dengan eksistensi militer Indonesia sebelum pemisahan TNI dan PoLRI, dimana militer yang terintegrasi dalam ABRI, komponennya terdiri dari TNI Angkatan Darat, Angkatan Laut, dan Angkatan Udara ditambah dengan PoLRI. Pemisahan kelembagaan TNI dan PoLRI dari $A B R I$ ternyata diikuti pula dengan perubahan paradigma sistem peradilan pidana (criminal justice system) yang berlaku bagi militer Indonesia, khususnya menyangkut yurisdiksi peradilan terhadap militer yang melakukan tindak pidana umum.

Perubahan paradigma sistem peradilan pidana tersebut dapat dilihat dari ketentuan Pasal 3 ayat (4) huruf a Ketetapan MPR Nomor VII/MPR/2000 yang menyatakan bahwa "Prajurit TNI tunduk kepada kekuasaan Peradilan Militer dalam hal pelanggaran hukum militer dan tunduk kepada kekuasaan Peradilan Umum dalam hal pelanggaran hukum pidana umum". Ketentuan Pasal 3 ayat (4) huruf a Ketetapan MPR Nomor VII/ MPR/2000 ini ternyata dipertegas kembali dalam Pasal 65 ayat (2) Undang-Undang Nomor 34 Tahun 2004 tentang Tentara Nasional Indonesia yang menyatakan bahwa "Prajurit TNI tunduk kepada kekuasaan Peradilan Militer dalam hal pelanggaran hukum pidana militer dan tunduk kepada kekuasaan Peradilan Umum dalam hal pelanggaran hukum pidana umum yang diatur dengan undang-undang".

Bertolak dari ketentuan Pasal 65 ayat (2) Undang-Undang Nomor 34 Tahun 2004 di atas, militer yang melakukan pelanggaran hukum pidana umum tunduk pada kekuasaan Peradilan Umum dan militer yang melakukan pelanggaran hukum pidana militer tunduk pada kekuasaan Peradilan Militer. Dengan kata lain, yurisdiksi peradilan terhadap militer yang melakukan pelanggaran hukum pidana diberikan kepada dua lingkungan peradilan yang berbeda, yaitu Peradilan Militer dan Peradilan Umum. Namun demikian, yurisdiksi Peradilan Umum terhadap militer yang melakukan tindak pidana umum sebagaimana diamanatkan oleh Pasal 3 ayat (4) huruf a Ketetapan MPR Nomor VII/MPR/2000 dan Pasal 65 ayat (2) Undang-Undang Nomor 34 Tahun 2004 tersebut belum dapat diimplementasikan di dalam praktik peradilan. Dengan kata lain, yurisdiksi peradilan terhadap militer pelaku tindak pidana umum masih dilaksanakan oleh Peradilan Militer. Hal tersebut disebabkan karena adanya Ketentuan Peralihan yang terdapat dalam Pasal 74 Undang-Undang Nomor 34 Tahun 2004. Dalam Pasal 74 ayat (1) Undang-Undang Nomor 34 Tahun 2004 ditegaskan bahwa "Ketentuan sebagaimana dimaksud dalam Pasal 65 berlaku pada saat undang-undang tentang Peradilan Militer yang baru diberlakukan". Pasal 74 ayat (2) menyatakan lebih lanjut bahwa "Selama undang-undang Peradilan Militer yang baru belum dibentuk, tetap tunduk pada ketentuan Undang-Undang Nomor 31 Tahun 1997 tentang Peradilan Militer".

Pasal 74 Undang-Undang Nomor 34 Tahun 2004 di atas pada hakikatnya mengamanatkan dibentuknya UndangUndang Peradilan Militer yang baru sebagai pengganti dari Undang-Undang Nomor 31 Tahun 1997. Selama Undang-Undang 
Peradilan Militer yang baru belum dapat direalisasikan pembentukannya, maka militer yang melakukan tindak pidana umum akan tetap tunduk pada yurisdiksi Peradilan Militer sesuai dengan Undang-Undang Nomor 31 Tahun 1997. Hal ini berarti bahwa yurisdiksi peradilan terhadap militer pelaku tindak pidana umum masih akan dijalankan oleh Peradilan Militer hingga terbentuknya UndangUndang Peradilan Militer baru. Kenyataannya, pembentukan Undang-Undang Peradilan Militer yang baru sebagaimana diamanatkan Pasal 74 Undang-Undang Nomor 34 Tahun 2004 belum dapat diwujudkan sampai dengan tahun 2013.

Perlu dikemukakan bahwa Dewan Perwakilan Rakyat (DPR) 1999-2004 sebenarnya telah mengupayakan agar dibuat suatu undang-undang baru yang mengatur bahwa militer yang melakukan tindak pidana umum dapat diadili di Peradilan Umum (Redaksi Kompas, Kompas, 13 Maret 2000). Bahkan Badan Musyawarah (Bamus) DPR telah merumuskan naskah perubahan terhadap Undang-Undang Nomor 31 Tahun 1997 tentang Peradilan Militer dan dalam rapat paripurna yang dilaksanakan tanggal 24 Mei 2004, seluruh fraksi menyetujui Rancangan Undang-Undang (RUU) usul inisiatif yang diajukan DPR mengenai Perubahan Undang-Undang Nomor 31 Tahun 1997 untuk ditetapkan menjadi usul DPR (Redaksi Kompas, Kompas 25 Mei2004).

RUU Perubahan terhadap UndangUndang Nomor 31 Tahun 1997 ternyata tidak sempat dilakukan pembahasan oleh DPR 1999-2004 hingga akhir masa tugasnya, sehingga RUU tersebut diajukan oleh DPR periode berikutnya (2004-2009). RUU Perubahan terhadap Undang-Undang Nomor 31 Tahun 1997 dalam perkembangannya telah dimasukkan ke dalam Daftar Prioritas RUU Program Legislasi Nasional (Prolegnas) berdasarkan Keputusan DPR RI No. 01/ DPR-RI/III/2004-2005. Setelah masuk Daftar Prioritas RUU Prolegnas, dalam Rapat Paripurna DPR bulan Mei 2005 seluruh fraksi sepakat mengajukan hak inisiatif untuk merevisi Undang-Undang Nomor 31 Tahun 1997. Berdasarkan Keputusan DPR tersebut dibentuklah Panitia Khusus (Pansus) RUU Perubahan Atas Undang-Undang Nomor 31 Tahun 1997 tentang Peradilan Militer pada tanggal 28 Juni 2005 (Imparsial, 2007: 24).

Namun demikian, pembahasan revisi Undang-Undang Nomor 31 Tahun 1997 oleh
DPR dan Pemerintah (Menteri Pertahanan dan Menteri Hukum dan Hak Asasi Manusia) mengalami jalan buntu (deadlock) karena terjadi perbedaan pendapat antara DPR dan Pemerintah, khususnya menyangkut draf Pasal 9 yang mengatur yurisdiksi Peradilan Militer. Dalam pembahasan revisi Undang-Undang Peradilan Militer itu, DPR menginginkan agar prajurit TNI yang melakukan pelanggaran hukum pidana umum (tindak pidana umum) diadili di Peradilan Umum tanpa melihat oknumnya. Sebaliknya, Pemerintah menginginkan semua prajurit TNI diadili di Peradilan Militer tanpa melihat bentuk tindak pidananya, baik tindak pidana militer maupun tindak pidana umum (www. antarajateng.com, 5 April 2013). Akibatnya, pembahasan revisi Undang-Undang Nomor 31 Tahun 1997 tentang Peradilan Militer tersebut tidak ada kejelasan hingga saat ini, karena revisi Undang-Undang Peradilan Militer memang tidak termasuk dalam agenda pembahasan legislasi 2009-2014 (Redaksi Kompas, Kompas, 5 April 2013).

2. Persepsi Kalangan Militer Mengenai Konsepsi Yurisdiksi Peradilan Terhadap Prajurit Tentara Nasional Indonesia Sebagai Pelaku Tindak Pidana.

Dalam kaitannya dengan konsepsi yurisdiksi peradilan terhadap prajurit TNI yang melakukan tindak pidana, maka dapat dikemukakan berbagai pendapat yang berkembang di tengah masyarakat, baik dari kalangan sipil maupun kalangan militer sendiri. Pendapat dari kalangan sipil pernah dikemukakan oleh para guru besar hukum pidana seperti Muladi, Mardjono Reksodiputro, Andi Hamzah dan F. Sugeng Istanto (Wahyoedho Indrajit, 2002:7-8 dan 250-251). Muladi mengemukakan bahwa pengadilan militer masih diperlukan, tetapi hanya terbatas pada perkara yang khas militer, dimana orang sipil tidak bisa melakukannya, seperti desersi dan insubordinasi. Tindak pidana lainnya seperti mencuri senjata, mencuri rahasia militer, berbuat zina, korupsi dan sebagainya, meskipun hal tersebut terjadi di dalam markas atau berkaitan langsung dengan tugas atau jabatan militer, tetap dibawa ke peradilan umum dan disidik oleh polisi, karena tindak pidana tersebut bukan khas militer.

Mardjono Reksodiputro menyatakan bahwa tentara apabila melakukan tindakan yang menyangkut hukum kemiliteran, 
memang ada pengadilan khusus yang menyelesaikan, yaitu pengadilan militer, tetapi yang menjadi permasalahan di Indonesia adalah tentara yang melakukan delik biasa juga larinya ke pengadilan militer. Seharusnya pengadilan militer mengadili delik-delik yang ada kaitannya dengan kepentingan tentara, seperti pencurian senjata, pencurian data atau rahasia tentara dan sebagainya.

Andi Hamzah berpandangan bahwa peradilan militer hanya mengadili pelanggaran yang murni militer saja, seperti desersi. Demikian pula, F. Sugeng Istanto menyatakan bahwa kompetensi peradilan militer sebaiknya dibatasi pada tindak pidana yang berkaitan dengan bidang ketentaraan, seperti desersi, pencurian alat-alat perang dan lain-lain.

Dalam hubungannya dengan hal tersebut di atas, Harkristuti Harkrisnowo pernah mengusulkan agar dilakukan penyempitan ruang lingkup tindak pidana yang dilakukan oleh TNI yang menjadi kewenangan peradilan militer, yaitu dibatasi pada tindak pidana yang dilakukan oleh anggota TNI yang berkenaan dengan jabatannya dalam kemiliteran. Termasuk dalam kategori ini pula adalah tindak pidana yang akan memberikan dampak pada kinerja TNI, seperti yang berkenaan dengan informasi atau pendataan dalam lembaga dan juga yang dilakukan terhadap sarana dan prasarana militer (Harkristuti Harkrisnowo (makalah), 2000: 8).

Pandangan dari kalangan militer (TNI) antara lain dikemukakan oleh Laksamana Muda TNI N. Tarigan yang pernah menjabat sebagai Pelaksana Mahkamah Militer Agung dan Brigadir Jenderal TNI Bachrudin, mantan Kepala Biro Hukum Departemen Pertahanan (Wahyoedho Indrajit, 2002: 274-276). N. Tarigan menyatakan agar semua tindak pidana yang dilakukan oleh anggota TNI di dalam markas tetap menjadi kewenangan Peradilan Militer. Hal tersebut didasarkan pada pertimbangan bahwa, meskipun tindak pidana yang dilakukan di dalam markas/kesatrian atau pangkalan dikategorikan sebagai tindak pidana umum, misalnya zina (Pasal 284 KUHP), tetapi dianggap dapat mempengaruhi mental atau kekompakan pasukan yang pada akhirnya akan mempengaruhi kinerja pasukan. Pendapat tersebut didasarkan pada pertimbangan bahwa tradisi keprajuritan seperti cepat bereaksi, le esprit de corps, kesetiakawanan, berani dan rela berkorban, menjadikan setiap anggota TNI sangat rawan dalam kecenderungan menolak, bahkan melawan terhadap orang lain (bukan anggota TNI) yang masuk untuk menangani masalahmasalah yang menyangkut anggota TNI atau kesatuannya. Lebih rentan lagi, karena dalam tugasnya anggota TNI memegang senjata.

Bachrudin mengemukakan pendapatnya bahwa apabila ketentuan Pasal 3 ayat (4) huruf a Ketetapan MPR No. VII/MPR/2000 akan diterapkan, maka perkara-perkara yang menjadi kompetensi Peradilan Militer adalah (1) semua tindak pidana yang diatur dalam KUHPM; (2) tindak pidana umum yang dilakukan oleh anggota TNI dalam dinas militer; (3) tindak pidana umum yang dilakukan oleh anggota TNI dalam markas, kesatrian, asrama dan kapal/pesawat; dan (4) tindak pidana umum yang dilakukan oleh prajurit dalam keadaan darurat militer dan keadaan perang.

Mayor Warsono, Wakil Kepala Pengadilan Militer II-11 Yogyakarta mengemukakan pendapatnya bahwa Peradilan Umum yang menangani prajurit TNI yang melakukan tindak pidana umum akan merusak sendisendi militer, karena Peradilan Umum tidak memiliki pemahaman mengenai militer. Prajurit TNI adalah orang terpilih dari ujung kaki sampai ujung rambut, oleh sebab itu jika seorang prajurit TNI melakukan suatu pelanggaran atau kejahatan maka yang harus menghukum atau memproses adalah orang militer itu sendiri yang mengetahui dan memahami tentang militer. Seharusnya revisi peradilan diarahkan kepada upayaupaya untuk memperkuat kelembagaan, dan bukan menggoyahkan tatanan yang sudah mapan, dalam hal ini Peradilan Militer (Wawancara dengan Mayor Warsono, Wakil Kepala Pengadilan Militer II-11 Yogyakarta, September 2013).

Pendapat yang hampir sama dikemukakan oleh Kepala oditurat Militer II11 Yogyakarta, Letnan Kolonel Sus Budiharto, S.H., MH, bahwa revisi Undang-Undang Nomor 31 tahun 1997 tentang Peradilan Militer semakin kehilangan arah karena yang mempunyai ide menundukkan TNI pada Peradilan Umum adalah pembentuk undang-undang periode 2004-2009 yang tidak menjabat lagi, tetapi ke depan masih dalam proses dan harus mempetimbangkan secara sosiologi, psikologis di dalam militer itu sendiri (Wawancara dengan Letkol Sus Budiharto, Kepala oditur Militer II-11 Yogyakarta, september 2013). 
Berdasarkan pendapat-pendapat tersebut terlihat adanya perbedaan pandangan mengenai yurisdiksi peradilan terhadap prajurit TNI yang melakukan tindak pidana. Berbagai pandangan tersebut dapat dikelompokkan mejadi 3 (tiga) macam. Pertama, pandangan yang menghendaki agar yurisdiksi Peradilan Militer hanya dibatasi pada tindak pidana yang "khas" militer atau pelanggaran yang "murni" militer, dalam pengertian bahwa tindak pidana tersebut hanya dapat dilakukan oleh orang-orang yang memiliki status sebagai anggota TNI, sedangkan orang-orang sipil tidak mungkin melakukan tindak pidana tersebut. Pandangan ini benar-benar ingin membatasi dan mempersempit yurisdiksi Peradilan Militer. Pandangan yang "sempit" ini dikemukakan oleh Muladi dan Andi Hamzah.

Kedua, pandangan yang menghendaki agar yurisdiksi Peradilan Militer meliputi tindak pidana yang dilakukan oleh anggota TNI yang berkenaan dengan jabatannya dalam kemiliteran atau berkaitan dengan bidang ketentaraan atau ada kaitannya dengan kepentingan tentara. Pandangan ini lebih luas dari pandangan yang pertama, karena yurisdiksi Peradilan Milter tidak hanya meliputi tindak pidana yang khas atau murni militer, melainkan juga tindak pidana lain yang berkaitan dengan kepentingan militer yang mana tindak pidana tersebut dapat dilakukan pula oleh orang-orang sipil, seperti pencurian senjata, pencurian alat-alat perang dan lain-lain. Pandangan yang lebih luas ini dikemukakan oleh Mardjono Reksodiputro, F. Sugeng Istanto dan Harkristuti Harkrisnowo.

Ketiga, pandangan yang menghendaki agar yurisdiksi Peradilan Militer tidak hanya meliputi tindak pidana yang khas atau murni militer dan tindak pidana lain yang berkaitan dengan kepentingan militer, melainkan juga tindak pidana umum yang dilakukan oleh anggota TNI di area militer, seperti markas, kesatrian, asrama militer dan lainlain. Dengan demikian, pandangan yang ketiga ini menghendaki perluasan yurisdiksi Peradilan Militer yang didasarkan pada tempat terjadinya tindak pidana (locus delicti). Pandangan yang paling luas ini dikemukakan dari kalangan militer, yaitu Laksamana Muda TNI N. Tarigan, Brigadir Jenderal TNI
Bachrudin, Mayor Warsono, dan Letnan Kolonel Sus Budiharto, S.H., MH

Namun demikian, Purnomo Yusgiantoro justru menyatakan dengan tegas bahwa sebaiknya DPR tidak perlu memprioritaskan revisi Undang-Undang Nomor 31 Tahun 1997 tentang Peradilan Militer, karena Undang-Undang tersebut masih relevan digunakan untuk mengadili anggota TNI yang melakukan tindak pidana. ${ }^{1} \mathrm{Hal}$ ini berarti Kementerian Pertahanan menginginkan agar yurisdiksi peradilan terhadap prajurit TNI yang melakukan tindak pidana, baik tindak pidana militer maupun tindak pidana umum, diserahkan kepada Peradilan Militer. Sehubungan dengan hal tersebut, Wakil Ketua DPR Pramono Anung pernah menegaskan bahwa DPR akan mengambil inisiatif untuk melanjutkan pembahasan RUU Peradilan Militer yang terbengkelai jika Pemerintah sudah tidak ada keinginan lagi untuk melanjutkannya (www.hukumonline. com, 5 April 2013).

\section{Simpulan}

Berdasarkan hasil penelitian dan pembahasan di atas dapat dikemukakan dua kesimpulan. Pertama, faktor utama yang menyebabkan belum diimplementasikannya yurisdiksi Peradilan Umum terhadap prajurit TNI yang melakukan tindak pidana umum adalah belum direalisasikannya revisi Undang-Undang Nomor 31 Tahun 1997 tentang Peradilan Militer. Hal ini tidak dapat dilepaskan dari ketentuan Pasal 74 UndangUndang Nomor 34 Tahun 2004 sebagai Ketentuan Peralihan yang mengamanatkan dibentuknya Undang-Undang Peradilan Militer baru yang menggantikan Undang-Undang Nomor 31 Tahun 1997. Selama Undang-Undang Peradilan Militer baru belum dapat direalisasikan pembentukannya, maka prajurit TNI yang melakukan tindak pidana, baik tindak pidana militer maupun tindak pidana umum, tetap tunduk pada yurisdiksi Peradilan Militer.

Kedua, persepsi kalangan militer mengenai konsepsi peradilan yang berwenang mengadili prajurit TNI yang melakukan tindak pidana, pada dasarnya tetap menginginkan agar prajurit TNI yang melakukan tindak pidana, baik tindak pidana militer maupun tindak pidana umum, berada pada yurisdiksi Peradilan Militer. 


\section{daftar Pustaka}

Darwan Prinst. 2003. Peradilan Militer. Bandung : citra Aditya Bakti

Harkristuti Harkrisnowo. 2000. "Redefinisi Tindak Pidana Militer Dalam Lingkup Peradilan Militer : Masalah Yurisdiksi". makalah dalam Semiloka tentang Implikasi Reposisi TNI-PoLRI di Bidang Hukum. 22-23 November 2000. Yogyakarta : Fakultas Hukum UGM.

Imparsial. 2007. Reformasi Peradilan Militer di Indonesia : Sebuah Analisa Kebijakan di Indonesia. Jakarta : Imparsial.

Muhammad Fajrul Falaakh. dkk. 2001. Implikasi Reposisi TNI-POLRI di Bidang Hukum. Yogyakarta : Fakultas Hukum Universitas Gadjah Mada.

Wahyoedho Indrajit.2002. "Prospek Peradilan Militer Dalam Sistem Peradilan Pidana Indonesia". Tesis. Jakarta : Program Pascasarjana Universitas Indonesia.

Redaksi Kompas. "DPR Benahi Peradilan Militer". Kompas. 25 Mei 2004.

. "Revisi UU Peradilan Militer". Kompas. 5 April 2013.

"Segera Revisi UU Peradilan Militer". Kompas. 13 Maret 2000.

Undang-Undang Dasar Negara Republik Indonesia Tahun 1945.

Ketetapan MPR No. VI/MPR/2000 tentang Pemisahan Tentara Nasional Indonesia dan Kepolisian Negara Republik Indonesia.

Ketetapan MPR No. VII/MPR/2000 tentang Peran Tentara Nasional Indonesia dan Peran Kepolisian Negara Republik Indonesia.

Undang-Undang Nomor 31 Tahun 1997 tentang Peradilan Militer. Lembaran Negara Republik Indonesia Tahun 1997 Nomor 84.

Undang-Undang Nomor 3 Tahun 2002 tentang Pertahanan Negara. Lembaran Negara Republik Indonesia Tahun 2002 Nomor 3.

Undang-Undang Nomor 34 Tahun 2004 tentang Tentara Nasional Indonesia. Lembaran Negara Republik Indonesia Tahun 2004 Nomor 34.

Undang-Undang Nomor 48 Tahun 2009 tentang Kekuasaan Kehakiman. Lembaran Negara Republik Indonesia Tahun 2009 Nomor 48.

“Wacana Revisi UU Militer Mengemuka Kembali”. www.antarajateng.com. 5 April 2013.

"DPR Didesak Inisiatif Bahas RUU Peradilan Militer". www.hukumonline.com. 5 April 2013. 